\title{
Determinants of Organizational Performance of Midwives in Antenatal Services in Very Remote Areas in Kupang Regency
}

\author{
Mariana Archoon Sailana ${ }^{1 *}$, Stefanus P.Manongga ${ }^{2}$, Idawati Trisno ${ }^{3}$, Pius Weraman ${ }^{4}$, Anderias Umbu Roga ${ }^{5}$ \\ ${ }^{1}$ Master Program in Public Health, Nusa Cendana University, NTT, Indonesia \\ ${ }^{2-5}$ Public Health Faculty, Nusa Cendana University, NTT, Indonesia
}

\section{Article History}

Received: 07.12.2020

Accepted: 22.12 .2020

Published: 30.12 .2020

Journal homepage:

https://www.easpublisher.com

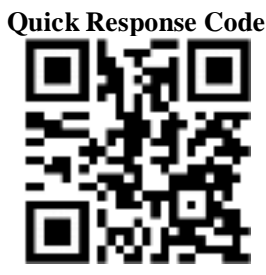

Abstract: Introduction: Antenatal care, which is one of the pillars of safe motherhood, is health services provided by health workers for mothers during their pregnancy, which are implemented in accordance with the antenatal service standards set out in the Midwifery Service Standards based on 10 T. Objective: The aim of this study was to analyze the determinants of the organization that affect the performance of midwives in implementing Antenatal Care (10T) in a very remote area of Kupang Regency. Material and Method: The number of research samples was 72 samples in 2019 with data collection techniques using documentation studies, namely the checklist sheet. Data were analyzed using simple logistic regression analysis and multiple logistic regressions. Results: The results showed that the factors that significantly correlated between organizational factors and the performance of midwives in implementing ANC according to $10 \mathrm{~T}$ standards were the completeness of infrastructure $(\mathrm{p}=0.0 .046 ; \mathrm{OR}=2.800)$ and leadership $(\mathrm{p}=0.006 ; \mathrm{OR}=4.185)$. The most significant determinant related between organizational factors and midwife performance in implementing ANC according to 10T standards in very remote areas in Kupang Regency was leadership ( $p=0.033 ;$ OR $=3,340 ; 95 \%$ CI: 1.103-10,118). Conclusion: In integrated Antenatal Care services, health workers must be able to ensure that the pregnancy takes place normally, improve the mother's health status, carry out various health efforts, both promotive, preventive and curative and rehabilitative, seek services for pregnant women, help deliveries by health workers, able to detect early problems and diseases experienced by pregnant women, intervene adequately so that pregnant women are ready to undergo normal delivery, family planning counseling services, and reproductive health.

Keywords: Determinants; Antenatal; Leadership.

Copyright (C) 2020 The Author(s): This is an open-access article distributed under the terms of the Creative Commons Attribution 4.0 International License (CC BY-NC 4.0) which permits unrestricted use, distribution, and reproduction in any medium for non-commercial use provided the original author and source are credited.

\section{INTRODUCTION}

Antenatal Care (ANC) is one of the early prevention efforts of pregnancy risk factors to early detect on the occurrence of high risks in pregnancy and childbirth as well as to reduce maternal mortality and monitor the condition of the fetus. Ideally, if every pregnant woman checks her pregnancy, it aims to detect abnormalities that may occur in the pregnancy, quickly detect it, and can immediately be overcome before it has a bad effect on the pregnancy by doing Antenatal care [1]. Antenatal care, which is one of the pillars of safe motherhood, is health services provided by health workers for mothers during their pregnancy, which are carried out in accordance with the antenatal service standards stipulated in the Midwifery Service Standards based on 10T [2].

Based on the results of reporting by the Kupang Health Office, there are high risk factors detected by health workers in very remote areas (Fatumonas Health Center), namely there were 36 high- risk cases in 2019. This data is the highest case in very remote areas. This high number of cases requires the importance of implementing ANC according to standards to detect early on the high risk of pregnancy and childbirth, which can also reduce maternal and infant mortality rates. Furthermore, in 2019, there were 8 cases of maternal mortality in the Kupang Regency area with a classification of 1 death in very remote areas. The causes of death were bleeding (5 cases), hypertension in pregnancy ( 1 case), and amniotic fluid embolism (1 case). The direct cause of maternal death should be prevented if antenatal care is provided according to standards [3].

The good performance of health workers will have an impact on the quality of services, including the performance of midwives as providers of maternal and neonatal health services. If a woman can safely pass the pregnancy, childbirth, and postpartum processes, the Maternal Mortality Rate (MMR) in Indonesia can be reduced. A midwife must have extensive knowledge, have high motivation, are required to use abilities in 
various aspects of life, especially in providing services to patients, so that they can have a positive impact according to their field of knowledge [4].

Based on this background, the researcher wants to further investigate the factors that affect the performance of midwives in Antenatal Care Services according to the $10 \mathrm{~T}$ standard in very remote areas in Kupang Regency in 2019.

\section{RESEARCH MeTHOD}

This type of research is an observational analytic study using a cross sectional approach to analyze organizational determinants that affect the performance of midwives in implementing Antenatal Care (10T) in very remote areas. The population in this study were all midwives who were registered and devoted themselves to very remote health centers in Kupang Regency in 2019 totaling 101 midwives. The sample in this study was part of the population which was carried out by multistage random sampling by mapping health centers with rural categories, then the number of samples was taken based on systematic sampling based on the farthest area until the number of samples met the inclusion and exclusion criteria, 72 midwives were obtained.

The research was conducted in very remote Health Centers in Kupang Regency (14 Health Centers) in August - October 2020. The study used primary and secondary data with the independent variables used were infrastructure and midwife leadership, while the dependent variable was the performance of the midwife. Retrieval of data in this study using a checklist sheet. The analysis used was univariate analysis, bivariate analysis using simple logistic regression tests, and multivariate analysis using multiple logistic regression tests.

\section{RESULTS}

\section{Distribution of Respondent Characteristics}

Characteristics of respondents consisting of age and education can be seen in table 1 below;

Table-1: Characteristics of respondents

\begin{tabular}{|c|c|c|c|}
\hline No & $\begin{array}{c}\text { Characteristics of } \\
\text { respondents }\end{array}$ & n & $\%$ \\
\hline \multirow[t]{2}{*}{1} & $\begin{array}{c}\text { Midwife Age } \\
20-30 \text { thn } \\
>30 \text { thn }\end{array}$ & $\begin{array}{l}46 \\
26 \\
\end{array}$ & $\begin{array}{l}63,9 \\
36,1 \\
\end{array}$ \\
\hline & Total & 72 & 100 \\
\hline \multirow[t]{2}{*}{2} & $\begin{array}{c}\text { Last Education } \\
\text { DI-DII } \\
\geq \text { DIII } \\
\end{array}$ & $\begin{array}{c}71 \\
1 \\
\end{array}$ & $\begin{array}{c}98,6 \\
1,4 \\
\end{array}$ \\
\hline & Total & 72 & 100 \\
\hline
\end{tabular}

Based on Table 3.1, it can be seen that respondents in the performance of midwives in very remote health centers according to the age of midwives were mostly aged 20-30 years and according to the latest education at very remote health centers were mostly Associate's Degree (DI-DIII) graduates.

\section{Relationship between organizational determinants and performance of midwives}

To test the hypothesis, an analytical analysis was carried out on the independent variable and the dependent variable according to the data scale used. Furthermore, conducting analysis tests to see the effect of the independent variables on the dependent variable with a simple logistic regression test. For variables that have a relationship with a $\mathrm{p}$ value $<0.05$ at $95 \% \mathrm{CI}$ (Confidence Interval), the simple logistic regression test results are obtained in Table 2 below.

Table-2: Relationship between Organizational determinants and performance of midwives

\begin{tabular}{|c|c|c|c|c|c|c|c|c|}
\hline \multirow[t]{3}{*}{ Variable } & \multicolumn{4}{|c|}{ Very Remote Health Centers } & \multirow{2}{*}{\multicolumn{2}{|c|}{ Total }} & \multirow[t]{3}{*}{ P-value } & \multirow[t]{3}{*}{$O R$} \\
\hline & \multicolumn{2}{|c|}{$\begin{array}{c}\text { Poor } \\
\text { performance of } \\
\text { midwives }\end{array}$} & \multicolumn{2}{|c|}{$\begin{array}{c}\text { Good } \\
\text { performance } \\
\text { of midwives }\end{array}$} & & & & \\
\hline & $\mathrm{n}$ & $\%$ & $n$ & $\%$ & $n$ & $\%$ & & \\
\hline \multicolumn{9}{|l|}{ Infrastructure } \\
\hline Poor & 32 & 44,4 & 10 & 13,9 & 40 & 58,3 & \multirow[t]{3}{*}{0,046} & \multirow{3}{*}{2,800} \\
\hline Good & 16 & 22,2 & 14 & 19,4 & 30 & 41,7 & & \\
\hline Total & 48 & 66,6 & 24 & 33,3 & 142 & 100 & & \\
\hline \multicolumn{9}{|l|}{ Midwife Leadership } \\
\hline Poor & 32 & 44,4 & 10 & 13,8 & 42 & 58,2 & \multirow[t]{2}{*}{0,006} & \\
\hline Good & 13 & 18 & 17 & 23,6 & 30 & 41,8 & & 4,185 \\
\hline Total & 45 & 62,8 & 27 & 37,4 & 72 & 100 & & \\
\hline
\end{tabular}

From Table 2 above, it was obtained the simple logistic regression test results for the infrastructure variable, the p-value $=0.046$, which means that there was a significant relationship between infrastructure and midwife performance. The value of the Odds Ratio is 2,800, meaning that the lack of infrastructure had a 2,800 times greater opportunity for the performance of midwives in implementing ANC compared to good infrastructure. While the midwife leadership variable obtained $\mathrm{p}$ value $=0.006$, which 
means that there was a significant relationship between midwife leadership and midwife performance. The value of the Odds Ratio of 4.185 means that the lack of leadership was 4.185 times greater for the performance of midwives in ANC implementation compared to good leadership.

\section{Organizational determinants of midwife performance}

After the simple logistic regression test was carried out, the variable selection was carried out in the bivariate analysis which had a $\mathrm{p}$ value $<0.25$, so there were variables of infrastructure and leadership that passed the selection, then carried out multivariate analysis using multiple logistic regression tests. The final results are obtained in table 3 below;

Table-3: Results of the Final Model Multivariate Analysis

\begin{tabular}{|l|c|c|c|}
\hline Variable & P value & OR & $\begin{array}{l}\text { 95\% CI for } \\
\mathbf{E X P}(\mathbf{B})\end{array}$ \\
\hline Leadership & 0,033 & 3,340 & $\begin{array}{c}1,103- \\
10,118\end{array}$ \\
\hline
\end{tabular}

Based on the results of table 3 above, it was obtained the final model variable which simultaneously related to the performance of midwives in implementing ANC in very remote Health Centers in Kupang Regency, namely the leadership variable. The results of the analysis showed that the Odds ratio of the leadership variable was 3,340 , meaning that midwives with lack of leadership had a 33 times greater chance of having a midwife's performance in ANC implementation compared to midwives with good motivation. The value of Negelkerke R. Square was 0.286 which means that the performance validity of midwives in the implementation of ANC which could be explained by the leadership variable was $28.6 \%$, while $62.4 \%$ was explained by other variables. The Hosmer Lemeshow test value showed a chi-square value of 8.667 and a $p$ value of 0.277 from these results because the $\mathrm{p}$ value was $>0.05$, the model was able to predict its observation value or the model was acceptable.

\section{DISCUSSION}

\section{Relationship of Infrastructure and Performance of Midwives}

A health service facility is a tool and or a place used to carry out health service efforts, whether promotive, preventive, curative, or rehabilitative carried out by the government, the regional government or the community [5]. The facility is a physical facility that can process an input towards the desired output. Facility is a provider of physical equipment to provide convenience to its users, so that the needs of the facility users are met [6]. The facilities and infrastructure referred to in this study are facilities and infrastructure that support integrated ANC services according to the 10T standard. The facilities and infrastructure in this study use the guidelines for the Regulation of the Indonesian Minister of Health Number 28 of 2017 concerning Licensing and Implementation of Midwifery Practices.

The results of the research at very remote health centers showed that there was a significant relationship between infrastructure and the performance of midwives. All existing infrastructure in the health facilities in the Kupang Regency have provided complete facilities that can be used by midwives in providing ANC services, such as weighing weight, checking fundal height, measuring blood pressure, giving iron tablets, giving TT immunization, and so on. Only a small number of tools such as Fetal Dopplers exist but cannot be used properly because they are damaged. This study is in line with research conducted by [7] which found that there was a significant relationship between infrastructure and antenatal care with a value of $p=0.002$. This study is also in line with research conducted by [8] which found that there was a significant relationship between infrastructure and antenatal care with a $\mathrm{p}$ value $=0.021$. And this study is not in line with research conducted by [9] that found no significant relationship between the infrastructure and ANC services with a $\mathrm{p}$ value $=0.714$.

A Health Center as a primary level health service provider has standard facilities and infrastructure that must be met in order to improve the quality of services to the community. Based on the regulation of the Minister of Health Number 75 of 2014, the construction of a Health Center must meet the following requirements; administrative requirements, work safety requirements, building technical requirements, are permanent and separate from other buildings, providing safety, health, and comfort functions. Standard facilities in health centers have also been regulated in the Minister of Health number 75 of 2014, among which the health center must have facilities for ventilation, lighting, sanitation, electricity, communication, medical gas, lightning protection, fire protection, noise control, vertical transportation systems (for buildings 2nd floor or more), mobile health centers, and ambulances.

\section{The Relationship between Midwife Leadership and Midwife Performance}

Leadership is the essence of management, because leadership is the driving force for human resources and other natural resources. Lack of maintenance and attention to ordinary workers leads to low morale, fatigue, and boredom and slowness in completing work, which in turn reduces work performance [10].

The results of the research at very remote health centers showed that there was a significant relationship between midwife leadership and midwife performance. This study is in line with research [11] which stated that respondents gave a good category to 
the leadership of the head of the health center more $(52 \%)$ than in the poor category $(2 \%)$. Furthermore [12], stated that there was a relationship between leadership and midwife performance, namely the value of $\mathrm{p}=0.006$ means that Ho was rejected and $\mathrm{Ha}$ was accepted. The results of statistical tests with Chi-Square obtained that the value of $\rho=0.00$ was smaller than $\alpha=$ $0.05(\rho<0.005)$, which means that Ho was rejected and Ha was accepted. Thus, there is a relationship between the leadership of the community health center leader and the performance of midwives in antenatal care services in health centers in Gowa Regency.

A leader must have holistic leadership skills, strategic leadership, managerial leadership, and sustainable leadership. Holistic leadership means a leader should be an "agent of change". Strategic leadership means the ability to respond appropriately and quickly to the turbulence of environmental changes that occur in the working area of the Health Center. Managerial leadership means the ability to mobilize health program management in accordance with existing program standards, as well as mobilizing Health Center human resources to implement these program standards with effective motivation, communication, and supervision techniques. Sustainable leadership means the opportunity for leaders to build personal and social relationships with the Health Center's staff, government officials, and the communities they serve. A leader must have management knowledge and leadership knowledge. Thus, the Head of the MCH Department at the Inpatient Community Health Center must always increase his knowledge of Management and Leadership.

\section{CONCLUSION}

The conclusion of this study is that there is a significant relationship between midwife leadership and the performance of midwives in implementing Antenatal Care (10T) in a very remote area of Kupang Regency.

\section{RECOMMENDATION}

Health workers, in this case midwives, can provide integrated and quality Antenatal Care services to improve maternal health status, as well as carry out various maternal health efforts which are promotive, preventive, curative, and rehabilitative.

\section{ACKNOWLEDGEMENT}

Special thanks for the services of the Kupang Health Office to me and all health centers' staff in the village area of Kupang Regency who have given permission to carry out research in the midst of the Covid-19 virus pandemic that has hit this beloved earth. Thank you also to other parties who have helped the process of carrying out this research.

\section{REFERENCES}

1. Saifudin, A.B. (2016). Panduan Praktis Pelayanan Kesehatan maternal dan Perinatal. Jakarta: YBSSP.

2. Data, P. (2014). Informasi Kementerian Kesehatan RI. Situasi dan analisis HIV AIDS.

3. Dinas Kesehatan Kabupaten Kupang NTT. (2019). Pofil Kesehatan Kabupaten Kupang NTT 2019. Kupang.

4. Manuaba, Ida, A.C. (2013). Ilmu Kebidanan, Penyakit Kandungan, DAN KB untuk pendidikan Bidan, Edisi 2. Jakarta.

5. Kemenkes, R. I. (2014). Pelayanan kesehatan masa sebelum hamil, masa hamil, persalinan, dan masa sesudah melahirkan, penyelenggaraan pelayanan kontrasepsi, serta pelayanan kesehatan seksual. Jakarta: Peraturan Menteri Kesehatan Republik Indonesia Nomor 97 tahun 2014.

6. Abu, A. D. K. H., Kusumawati, Y., \& Werdani, K. E. (2017). Hubungan karakteristik bidan dengan mutu pelayanan antenatal care berdasarkan standar operasional. Jurnal Kesehatan Masyarakat Andalas, 10(1), 94-100.

7. Nisa, K., Serudji, J., \& Sulastri, D. (2019). Analisis Faktor yang Berhubungan dengan Kinerja Bidan dalam Memberikan Pelayanan Antenatal Berkualitas Diwilayah Kerja Puskesmas Kota Bukittinggi Tahun 2018. Jurnal Ilmiah Universitas Batanghari Jambi, 19(1), 53-60.

8. Wahyuningsih, S., Yuwono, Y., \& Lionardo, A. (2018). Faktor-faktor yang mempengaruhi kepatuhan bidan terhadap standar pelayanan antenatal di kota palembang. Jurnal Kedokteran dan Kesehatan: Publikasi Ilmiah Fakultas Kedokteran Universitas Sriwijaya, 5(2), 96-107.

9. Yanidrawati, K. (2012). Hubungan kepuasan kerja dengan kinerja perawat di ruang rawat inap rumah sakit umum daerah kabupaten bekasi. Students $e$ Journal, 1(1), 32.

10. Hamidah, S. (2012). Faktor-Faktor yang Berpengaruh terhadap Kinerja Bidan dalam Pelaksanaan Standar Asuhan Kebidanan Ante Natal Care di Puskesmas Rawat Inap Kabupaten Gresik Tahun 2012 (Doctoral dissertation, UNIVERSITAS DIPONEGORO).

11. SUPARJO, S. (2003). Analisa faktor-faktor yang mempengaruhi kinerja bidan pegawai tidak tetap (ptt) di desa dalam pelayanan antenatal di kabupaten kudus (Factors that influence the workability of vilalage impermanent nurse in antenatal servise in Kudus regency) (Doctoral dissertation, Program Pascasarjana Universitas Diponegoro).

12. Yatino. (2005). Analisis Kinerja Bidan Desa dan Hubungannya dengan keberhasilan program perbaikan gizi dan kesehatan di kabupaten lampung barat. Skripsi Depertemen Gizi dan Sumberdaya Keluarga Fakultas Pertanian IPB. 